\title{
BENDING OF RING PLATES, PERFORMED FROM AN ORTHOTROPIC NONLINEAR DIFFERENTLY RESISTANT MATERIAL
}

\author{
Alexandr A. Treschev, Evgeniy A. Zhurin \\ Tula State University, Tula, RUSSIA
}

\begin{abstract}
This article proposes a mathematical model of axisymmetric transverse bending of an annular plate of average thickness, the loading of which is assumed to be on the upper surface of a transverse uniformly distributed load. An orthotropic plate made of a material whose mechanical characteristics nonlinearly depend on the type of stress state is considered. The most universal, built in the normalized tensor space of stresses associated with the main axes of anisotropy of the material are taken as defining relations. The loads were taken in such a way that the deflections of the middle surface of the plate could be considered small compared to its thickness. Fastening plates are presented in two versions: 1) rigid fastening on the outer and inner contours; 2) hinge bearing on the outer and inner contours. As a result of the formulation of the boundary value problem, a mathematical model was developed for the class of problems in question, implemented as a numerical algorithm integrated into the application package of the MatLAB environment. To solve the system of resolving differential equations of plate bending, the method of variable parameters of elasticity was used with a finitedifference approximation of the second order of accuracy.
\end{abstract}

Key words: transverse bending, axisymmetric deformation, ring plate, orthotropic material, nonlinear dissociation, small deflections

\section{ИЗГИБ КОЛЬЦЕВЫХ ПЛАСТИН, ВЫПОЛНЕННЫХ ИЗ ОРТОТРОПНОГО НЕЛИНЕЙНО РАЗНОСОПРОТИВЛЯЮЩЕГОСЯ МАТЕРИАЛА}

\author{
А.А. Трещев, Е.А. Журин \\ Тульский государственный университет, г. Тула, РОССИЯ
}

\begin{abstract}
Аннотация. В представленной статье предлагается математическая модель осесимметричного поперечного изгиба кольцевой пластины средней толщины, нагружение которой предполагается по верхней поверхности поперечной равномерной распределённой нагрузкой. Рассматривается ортотропная пластина, выполненная из материала, механические характеристики которого нелинейно зависят от вида напряженного состояния. В качестве определяющих соотношений приняты наиболее универсальные, построенные в нормированном тензорном пространстве напряжений, связанном с главными осями анизотропии материала. Величины нагрузок принимались с таким расчетом, чтобы прогибы срединной поверхности пластины могли считаться малыми по сравнению с ее толщиной. Закрепления пластин представлены в двух вариантах: 1) жёсткое закрепление по внешнему и внутреннему контурам; 2) шарнирное опирание по внешнему и внутреннему контурам. В результате постановки краевой задачи была разработана математическая модель для рассматриваемого класса задач, реализованная в виде численного алгоритма интепритированного в пакет прикладных программ среды MatLAB. Для решения системы разрешающих дифференциальных уравнений изгиба пластин использовался метод переменных параметров упругости с конечно-разностной аппроксимацией второго порядка точности.
\end{abstract}

Ключевые слова: поперечный изгиб, осесимметричное деформирование, кольцевая пластина, ортотропный материал, нелинейная разносопротивляемость, малые прогибы 


\section{INTRODUCTION}

Currently, more and more often designed and built buildings, manufactured parts of machines and devices, which until recently had no analogues. These objects require deformationstrength calculation of high accuracy, as the slightest error at the initial stage of design can lead to serious accidents.

Over time, more and more technological materials are created for which the theory of calculation of traditional (classical) materials is not acceptable. That is why the development of new and modernization of old models is an urgent task of modern construction and engineering.

It is obvious that researchers need not only to develop a mathematical model, but also to test it experimentally, and compare it with other models for similar designs. With a deeper study of the materials it will be possible to calculate the components and structural elements with minimal errors. This will allow you to develop a design without waste of material.

In this paper we consider the axisymmetric deformation of the annular plate of medium thickness. The plate material is adopted orthotropic. The nonlinear properties of the material appear already in the early stages of deformation and strongly affect the subsequent stress distribution. It is not possible to reliably describe the deformation of such a plate by conventional linear functions.

The development of the theory of calculation of plates of resistive anisotropic materials have been studied by many scholars such as S.A. Ambartsumyan, R.M. Jones, C.W. Bert, A.V. Berezin, A.A. Zolochevsky, N.M. Matchenko, A.A. Treshchev and others [1-33].

S.A. Ambartsumyan in his works $[1,2,3]$ proposed the simplest variants of defining relations in the form of equations of state. In the framework of the theory of small elastic deformations, piecewise linear relations between the principal stresses and strains were established, and the question of the relations between shear stresses and shear was not discussed. In S. A. Ambartsumyan's model [1, $2,3]$ the field of principal stresses is divided into regions of the first and second genera $[3,4$, 5]. This model is similar in form to the classical generalized Hooke's law of orthotropic matter, but the elastic moduli and the coefficients of transverse deformation in the directions of the principal axes are determined separately from the experiments on axial tension $\left(\mathrm{E}_{\mathrm{k}}{ }^{+}, \mathrm{v}_{\mathrm{km}}{ }^{+}\right)$and compression $\left(\mathrm{E}_{\mathrm{k}}{ }^{-}, \mathrm{v}_{\mathrm{km}}{ }^{-}\right)$. The direct application of the proposed relations is possible only in cases when the distribution of the principal stresses by their signs at different points of the body is known in advance, and also if the model constraints on the constants arising from the symmetry condition of the compliance tensor are observed.

Model R.M. Jones [6, 7, 8, 9] it is based on the construction of a matrix of weighted malleability, the symmetry of which in areas with different signs of the main stresses is achieved by introducing weight coefficients into the non-diagonal components. The weights represent the pairwise correlation of modules in the principal stresses

$$
k_{1}=\left|\sigma_{1}\right| /\left(\left|\sigma_{1}\right|+\left|\sigma_{2}\right|\right), \quad k_{2}=\left|\sigma_{2}\right| /\left(\left|\sigma_{1}\right|+\left|\sigma_{2}\right|\right) .
$$

The simplest model of equations of state for anisotropic multimodule bodies is proposed by C.W. Bert $[10,11,12,13]$. This model is applicable to fibrous materials when it is considered that the components of the compliance matrix depend on the sign of normal stresses arising in the direction of the fibers, that is, when stretching along the fibers, one symmetric matrix of compliance is used, when compressing - another. The rigor of this model is violated when the normal stresses along the fibers are equal to zero.

A more complex, but no less controversial model is proposed by A.A. Zolochevsky [14, $15,16,17,18,19,20,21]$, which introduced an equivalent stress, the second degree of which is determined by the potential of deformation. Potential constants are "hidden" in expressions that make up the equivalent voltage. The 
equivalent stress is determined by the sum of the linear and quadratic joint in-stress variants. Due to the presence of irrationality in the stressstrain coupling equations, it is not possible to distinguish the compliance matrix in General. The obtained nonlinear relations are sufficiently complex and contain a large number of constants to be experimentally determined. In particular, for an orthotropic material in a quasilinear approximation, it is necessary to determine thirty-two constants, and only 18 of the simplest reference experiments (uniaxial tension and contraction in the direction of the main axes of orthotropy and at an angle of $45^{\circ}$ to them) can be established.

\section{METHODS}

It is obvious that even a detailed analysis of the most well-known models of determining ratios of anisotropic materials of different resistances indicates that these models are not free from serious shortcomings and are based on separate hypotheses, often unfounded by experimental facts. In particular, E.V. Lomakin in [22, 23] formulates the strain potential for anisotropic materials in the form of an energy function from the ratio of the mean stress to the stress intensity

$$
\xi=\sigma / \sigma_{i}
$$

(where

$$
\sigma=\sigma_{i j} \cdot \delta_{i j} / 3
$$

- average stress,

$$
\sigma_{i}=\sqrt{1,5 S_{i j} S_{i j}}
$$

- stress intensity;

$$
S_{i j}=\sigma_{i j}-\delta_{i j} \sigma
$$

- stress deviator components; $\delta_{i j}$ - Kronecker symbol) multiplied by the convolution of the fourth rank compliance tensor with the second rank stress tensors in the principal axes of the anisotropy of the material. A serious drawback of the introduced relations is the discontinuity of the functional parameter $\xi$, which leads to uncertainties of an infinite nature, which has been repeatedly pointed out in [24, 25].

In the works of Matchenko N.M. and Treschev A.A. $[25,26]$ are the deformation potentials for anisotropic dissolving materials allowing the quasilinear approximation, normalized vector in nine-dimensional space of stresses. In these works the equations of state of two levels of accuracy are obtained. Despite the rationality of this approach, the obtained relations are also not free from significant drawbacks, which for the equations of the first level of accuracy are complex functional dependencies between uncorrelated constants of materials, and for the equations of the second level - an excessively large number of constants to be experimentally determined, which requires the involvement of experiments on complex stress States.

In subsequent works [27, 28, 29] Treschev A.A. carried out a corrective formulation of the equations of state for different classes of anisotropic materials, both in quasi-linear and in non-linear formulations. The nonlinear model [31] uses equations of state represented by the type of generalized Hooke's law for anisotropic materials by type:

$$
\begin{gathered}
e_{k m}=H_{k m p q}\left(\sigma_{i}, \alpha_{s t}\right) \cdot \sigma_{p q} ; \quad H_{k m p q}=H_{p q k m} ; \\
k, m, q, p, s, t,=1,2,3, \ldots
\end{gathered}
$$

In particular, for orthotropic material, these dependences are presented as follows:

$$
\begin{gathered}
e_{11}=\left(A_{1111}+B_{1111} \cdot \alpha_{11}\right) \cdot \sigma_{11}+ \\
+\left[A_{1122}+B_{1122} \cdot\left(\alpha_{11}+\alpha_{22}\right)\right] \cdot \sigma_{22}+ \\
+\left[A_{1133}+B_{1133} \cdot\left(\alpha_{11}+\alpha_{33}\right)\right] \cdot \sigma_{33} \\
e_{22}=\left[A_{1122}+B_{1122} \cdot\left(\alpha_{11}+\alpha_{22}\right)\right] \cdot \sigma_{11}+ \\
+\left(A_{2222}+B_{2222} \cdot \alpha_{22}\right) \cdot \sigma_{22}+ \\
+\left[A_{2233}+B_{2233} \cdot\left(\alpha_{22}+\alpha_{33}\right)\right] \cdot \sigma_{33}
\end{gathered}
$$




$$
\begin{gathered}
e_{33}=\left[A_{1133}+B_{1133} \cdot\left(\alpha_{11}+\alpha_{33}\right)\right] \cdot \sigma_{11}+ \\
+\left[A_{2233}+B_{2233} \cdot\left(\alpha_{22}+\alpha_{33}\right)\right] \cdot \sigma_{22}+ \\
+\left(A_{3333}+B_{3333} \cdot \alpha_{33}\right) \cdot \sigma_{33} ; \\
2^{e_{12}}=C_{1212}\left(\sigma_{i}\right) \cdot \tau_{12} ; \\
2^{e_{23}}=C_{2323}\left(\sigma_{i}\right) \cdot \tau_{23} ; \\
2 e_{13}=C_{1313}\left(\sigma_{i}\right) \cdot \tau_{13} \cdot{ }_{\beta_{k m}^{ \pm}}, \mu_{k m}^{ \pm}, \\
a_{k}^{ \pm}, m_{k}^{ \pm}, n_{k}^{ \pm}, \lambda_{k m}^{ \pm}, \beta_{k m}
\end{gathered}
$$

where

$$
a_{i j}=\sigma_{i j} / S
$$

- normalized stresses in the principal anisotropy axes of the material;

$$
S=\left(\sigma_{i j} \cdot \sigma_{i j}\right)^{0.5}=\sqrt{\sigma_{11}^{2}+\sigma_{22}^{2}+\sigma_{33}^{2}+2\left(\tau_{12}^{2}+\tau_{23}^{2}+\tau_{31}^{2}\right)}
$$

- module full voltage (norm of the space of stresses); $A_{i j k m}, B_{i j k m}, C_{i j k m}$, - nonlinear functions that determine the mechanical properties of a material.

For orthotropic bodies the number of independent material functions reaches fifteen [29, 30, 31]. The presentation of these functions, which determine the properties of the material, is carried out by approximating the experimental diagrams of deformation under uniaxial tension and compression along the main axes of anisotropy and diagrams obtained for shear in the three main planes of orthotropies by processing them in the program Microcal Origin Pro 8.0 (Microcal Software Inc.). In this case, for structural orthotropic nonlinearly resistive composite material AVCO Mod 3a [29, 30] are presented as follows:

$$
\begin{aligned}
& A_{k k k k}\left(\sigma_{i}\right)=0.5 \cdot\left[1 / E_{k}^{+}\left(\sigma_{i}\right)+1 / E_{k}^{-}\left(\sigma_{i}\right)\right] \\
& B_{k k k k}\left(\sigma_{i}\right)=0.5 \cdot\left[1 / E_{k}^{+}\left(\sigma_{i}\right)-1 / E_{k}^{-}\left(\sigma_{i}\right)\right] ; \\
& A_{k k m m}\left(\sigma_{i}\right)=-0.5 \cdot\left\lfloor\frac{v_{k m}^{+}\left(\sigma_{i}\right)}{E_{m}^{+}\left(\sigma_{i}\right)}+\frac{v_{k m}^{-}\left(\sigma_{i}\right)}{E_{m}^{-}\left(\sigma_{i}\right)}\right\rfloor ; \\
& B_{k k m m}\left(\sigma_{i}\right)=-0.5 \cdot\left\lfloor\frac{v_{k m}^{+}\left(\sigma_{i}\right)}{E_{m}^{+}\left(\sigma_{i}\right)}-\frac{v_{k m}^{-}\left(\sigma_{i}\right)}{E_{m}^{-}\left(\sigma_{i}\right)}\right\rfloor ;
\end{aligned}
$$

$$
\begin{gathered}
C_{k m k m}\left(\sigma_{i}\right)=1 / G_{k m}\left(\sigma_{i}\right) ; \\
E_{k}^{ \pm}\left(\sigma_{i}\right)=a_{k}^{ \pm}+m_{k}^{ \pm} \cdot \sigma_{i}+n_{k}^{ \pm} \cdot \sigma_{i}^{2} ; \\
v_{k m}^{ \pm}\left(\sigma_{i}\right)=\lambda_{k m}^{ \pm}+\beta_{k m}^{ \pm} \cdot \sigma_{i}+\mu_{k m}^{ \pm} \cdot \sigma_{i}^{2} ; \\
G_{k m}\left(\sigma_{i}\right)=g_{k m}+p_{k m} \cdot \sigma_{i}+q_{k m} \cdot \sigma_{i}^{2} .
\end{gathered}
$$

where $a_{k}^{ \pm}, m_{k}^{ \pm}, n_{k}^{ \pm}, \lambda_{k m}^{ \pm}, \beta_{k m}^{ \pm}, \mu_{k m}^{ \pm}, g_{k m}, p_{k m}, q_{k m}$ $p_{k m}, q_{k m}$ - the constants of nonlinear material functions determined by processing of experimental diagrams of deformation by the method of least squares and presented in table 1 .

This model of nonlinear orthotropic resistive material $[29,30,31]$ is currently the least controversial, gives the results as close as possible to the experimental data and therefore is the basis for the construction of the method of calculating the plates.

Consider the stress-strain state of the annular plate under loading by a transverse uniformly distributed load of intensity "q" (MPa). Material of plates taken with non-linear characteristic having cylindrical orthotropy and properties of resistivity. In this case, we focus on two options for the support of the object of study:

a) plate with rigidly clamped contours according to Figure 1a;

b) the plate is hinged on the contours in accordance with Figure 1b.

Due to the axial symmetry, the problems are considered taking into account the cylindrical coordinate system $(\mathrm{r}, \theta, \mathrm{z})$. In this case, the traditional model assumptions [30] are considered to be valid in the following form: 1) the normal to the median plane after deformation is rotated by an angle $\psi_{\theta}$ relative to the circumferential coordinate axis $\theta ; 2$ ) when determining the parameters of the stress state, the influence of normal stresses $\sigma_{z}$ is neglected due to their smallness.

Based on the above assumptions, for deformations at the points of the plate we have:

$$
\begin{gathered}
e_{r}=u_{, r}+z \cdot \psi_{\theta, r} ; \\
e_{\theta}=u / r+z \cdot \psi_{\theta} / r ; \\
\gamma_{r z}=w_{, r}+\psi_{\theta}
\end{gathered}
$$



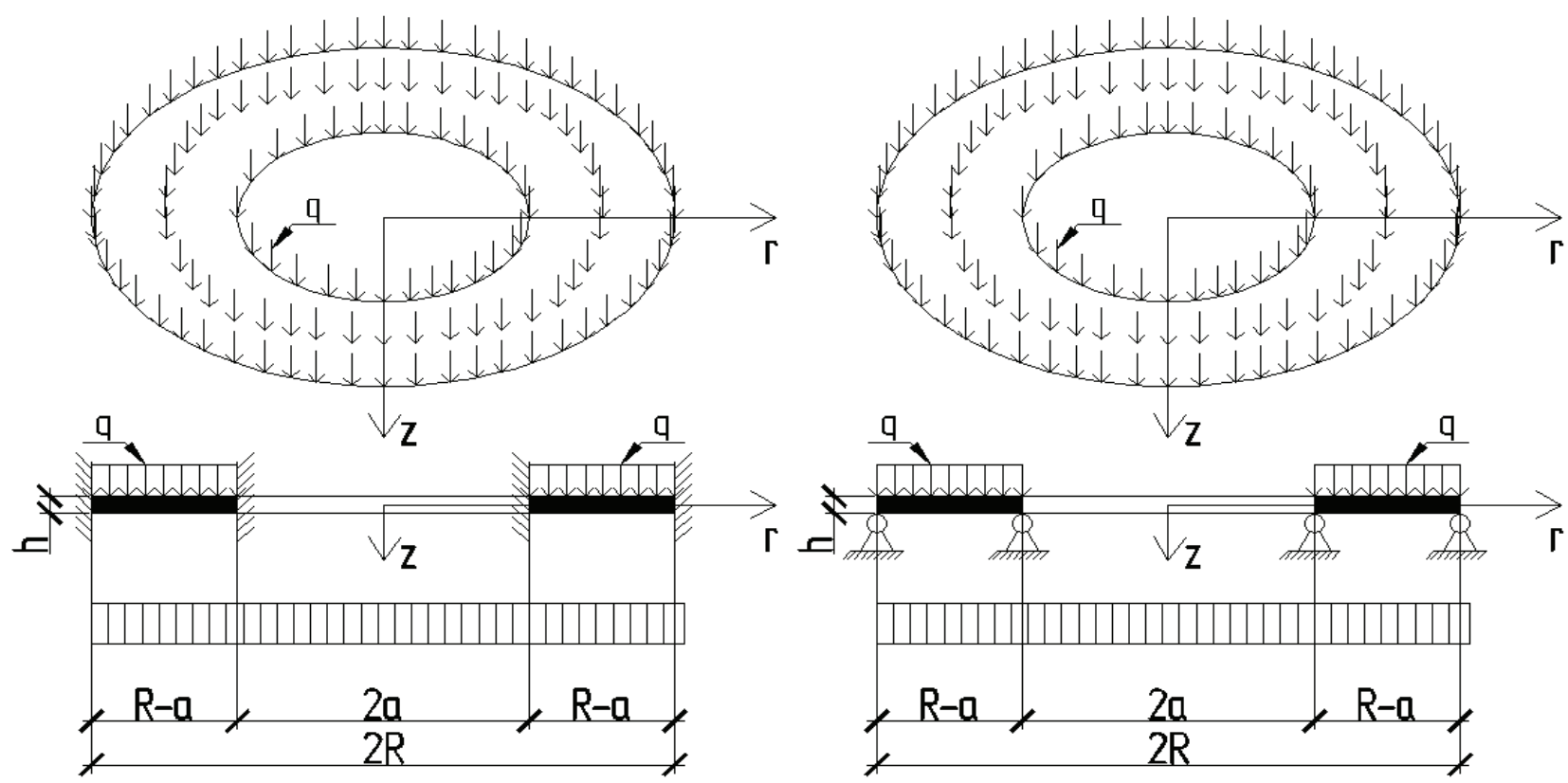

Figure 1. Design scheme of the ring plate with two types of support:

a) rigidly clamped circuits; b) pivotally supported circuits.

where $u$ - radial movements in the middle surface; $\psi_{\theta}-$ rotation angle of the plate section relative to the axis; $\theta ; w$ - deflection of the middle surface of the plate.

Taking into account the accepted hypotheses of equation (1) we transform to the form:

$$
\begin{gathered}
e_{r}=\left(A_{1111}\left(\sigma_{i}\right)+B_{1111}\left(\sigma_{i}\right) \cdot \alpha_{r}\right) \cdot \sigma_{r}+ \\
+\left[A_{1122}\left(\sigma_{i}\right)+B_{1122}\left(\sigma_{i}\right) \cdot\left(\alpha_{r}+\alpha_{\theta}\right)\right] \cdot \sigma_{\theta} ; \\
e_{\theta}=\left[A_{1122}\left(\sigma_{i}\right)+B_{1122}\left(\sigma_{i}\right) \cdot\left(\alpha_{r}+\alpha_{\theta}\right)\right] \cdot \sigma_{r}+ \\
+\left(A_{2222}\left(\sigma_{i}\right)+B_{2222}\left(\sigma_{i}\right) \cdot \alpha_{\theta}\right) \cdot \sigma_{\theta} ; \\
e_{z}=\left[A_{1133}\left(\sigma_{i}\right)+B_{1133}\left(\sigma_{i}\right) \cdot \alpha_{r}\right] \cdot \sigma_{r}+ \\
+\left[A_{2233}\left(\sigma_{i}\right)+B_{2233}\left(\sigma_{i}\right) \cdot \alpha_{\theta}\right] \cdot \sigma_{\theta} ; \\
e_{r z}=C_{1313}\left(\sigma_{i}\right) \cdot \tau_{r z} ;
\end{gathered}
$$

where

$$
\begin{gathered}
\alpha_{r}=\sigma_{r} / S ; \\
\alpha_{\theta}=\sigma_{\theta} / S ; \\
\alpha_{r z}=\sigma_{r z} / S ; \\
S=\sqrt{\sigma_{r}^{2}+\sigma_{\theta}^{2}+\tau_{r z}^{2}} ; \\
\sigma_{i}=\sqrt{\sigma_{r}^{2}-\sigma_{r} \cdot \sigma_{\theta}+\sigma_{\theta}^{2}+3 \tau_{r z}^{2}} .
\end{gathered}
$$

For the convenience of further presentation, we introduce the following designations:

$$
\begin{gathered}
C_{1111}=A_{1111}\left(\sigma_{i}\right)+B_{1111}\left(\sigma_{i}\right) \cdot \alpha_{r} ; \\
C_{1122}=A_{1122}\left(\sigma_{i}\right)+B_{1122}\left(\sigma_{i}\right) \cdot\left(\alpha_{r}+\alpha_{\theta}\right) ; \\
C_{1133}=A_{1133}\left(\sigma_{i}\right)+B_{1133}\left(\sigma_{i}\right) \cdot \alpha_{r} ; \\
C_{2222}=A_{2222}\left(\sigma_{i}\right)+B_{2222}\left(\sigma_{i}\right) \cdot \alpha_{\theta} ; \\
C_{2233}=A_{2233}\left(\sigma_{i}\right)+B_{2233}\left(\sigma_{i}\right) \cdot \alpha_{\theta} ; \\
C_{1313}=C_{1313}\left(\sigma_{i}\right) ;
\end{gathered}
$$

Having expressed stresses through deformations taking into account the simplifying equations (3)-(5), after simple mathematical manipulations we come to the following dependences:

$$
\begin{gathered}
\sigma_{r}=\Delta_{1111}\left(u_{, r}-z \cdot \psi_{\theta, r}\right)+\Delta_{1122}\left(u / r-z \cdot \psi_{\theta} / r\right) ; \\
\sigma_{\theta}=\Delta_{1122}\left(u_{, r}-z \cdot \psi_{\theta, r}\right)+\Delta_{2222}\left(u / r-z \cdot \psi_{\theta} / r\right) ; \\
\tau_{r z}=\frac{\left(\psi_{\theta}+w_{, 1}\right)}{\Delta_{1313}} ; \\
\Delta_{1111}=C_{2222} /\left(C_{1111} \cdot C_{2222}-C_{1122}^{2}\right) ; \\
\Delta_{1122}=C_{1122} /\left(C_{1111} \cdot C_{2222}-C_{1122}^{2}\right) ; \\
\Delta_{2222}=C_{1111} /\left(C_{1111} \cdot C_{2222}-C_{1122}^{2}\right) ; \\
\Delta_{1313}=C_{1313} ;
\end{gathered}
$$


Bending of Ring Plates, Performed from an Orthotropic Nonlinear Differently Resistant Material

Table 1. AVCO Mod 3a composite material constants [29, 30$].$

\begin{tabular}{|c|c|c|c|c|}
\hline $\begin{array}{c}\text { Type of prototype } \\
\text { test }\end{array}$ & $\begin{array}{l}\text { Technical } \\
\text { parameter }\end{array}$ & $\begin{array}{l}\text { The first element } \\
\text { of a nonlinear } \\
\text { function }\end{array}$ & $\begin{array}{l}\text { The second } \\
\text { element } \\
\text { of the nonlinear } \\
\text { function }\end{array}$ & $\begin{array}{l}\text { The third element } \\
\text { of the nonlinear } \\
\text { function }\end{array}$ \\
\hline 1 & 2 & 3 & 4 & 5 \\
\hline \multirow{16}{*}{ 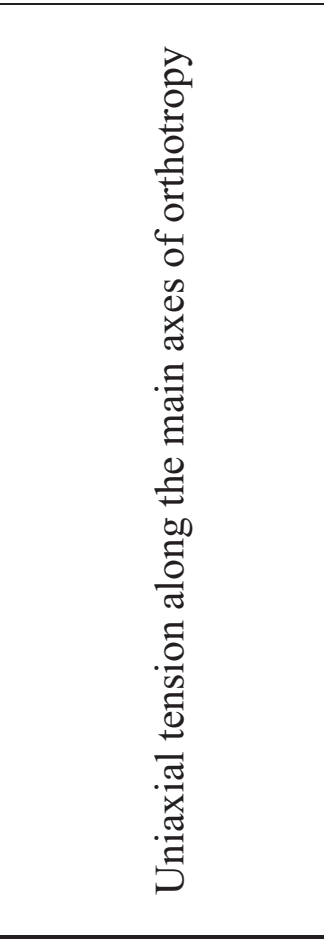 } & \multirow{6}{*}{$E_{k}^{+}\left(\sigma_{i}\right), \mathrm{Pa}$} & $\alpha_{1}^{+}$ & $m_{1}^{+}$ & $n_{1}^{+}$ \\
\hline & & $1.058 \cdot 10^{-10}$ & 62.829 & $1.535 \cdot 10^{-6}$ \\
\hline & & $\alpha_{2}^{+}$ & $m_{2}^{+}$ & $n_{2}^{+}$ \\
\hline & & $2.864 \cdot 10^{-10}$ & -105.476 & $5.893 \cdot 10^{-7}$ \\
\hline & & $\alpha_{3}^{+}$ & $m_{3}^{+}$ & $n_{3}^{+}$ \\
\hline & & $2.301 \cdot 10^{-10}$ & 88.349 & $3.711 \cdot 10^{-6}$ \\
\hline & \multirow{10}{*}{$v_{k m}^{+}\left(\sigma_{i}\right)$} & $\lambda_{12}^{+}$ & $\beta_{12}^{+}$ & $\mu_{12}^{+}$ \\
\hline & & 0.158 & $-3.106 \cdot 10^{-9}$ & $2.192 \cdot 10^{-17}$ \\
\hline & & $\lambda_{21}^{+}$ & $\beta_{21}^{+}$ & $\mu_{21}^{+}$ \\
\hline & & 0.103 & $-1.79 \cdot 10^{-9}$ & $9.106 \cdot 10^{-18}$ \\
\hline & & $\lambda_{13}^{+}$ & $\beta_{13}^{+}$ & $\mu_{13}^{+}$ \\
\hline & & 0.203 & $2.15 \cdot 10^{-9}$ & $6.148 \cdot 10^{-17}$ \\
\hline & & $\lambda_{23}^{+}$ & $\beta_{23}^{+}$ & $\mu_{23}^{+}$ \\
\hline & & 0.104 & $0.87 \cdot 10^{-10}$ & $6.741 \cdot 10^{-17}$ \\
\hline & & $\lambda_{31}^{+}$ & $\beta_{31}^{+}$ & $\mu_{31}^{+}$ \\
\hline & & 0.146 & $-0.146 \cdot 10^{-10}$ & $6.971 \cdot 10^{-17}$ \\
\hline \multirow{16}{*}{ 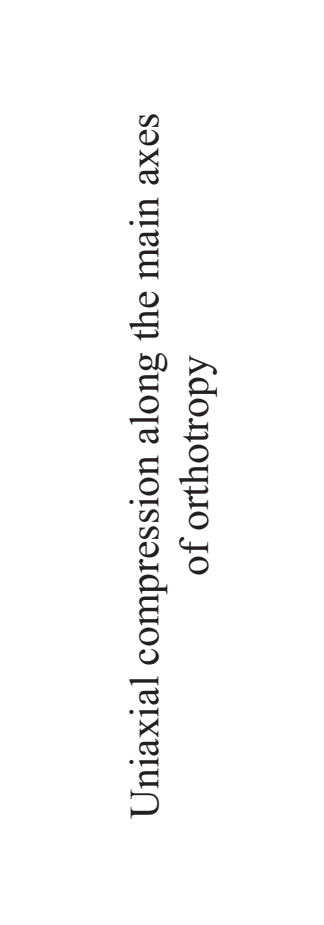 } & \multirow{6}{*}{$E_{k}^{-}\left(\sigma_{i}\right), \mathrm{Pa}$} & $\alpha_{1}^{-}$ & $m_{1}^{-}$ & $n_{1}^{-}$ \\
\hline & & $9.988 \cdot 10^{9}$ & -12.943 & $6.71 \cdot 10^{-7}$ \\
\hline & & $\alpha_{2}^{-}$ & $m_{2}^{-}$ & $n_{2}^{-}$ \\
\hline & & $2.326 \cdot 10^{10}$ & -436.81 & $-6.077 \cdot 10^{-7}$ \\
\hline & & $\alpha_{3}^{-}$ & $m_{3}^{-}$ & $n_{3}^{-}$ \\
\hline & & $5.14 \cdot 10^{9}$ & -129.15 & $-78.31 \cdot 10^{-6}$ \\
\hline & \multirow{10}{*}{$v_{k m}^{-}\left(\sigma_{i}\right)$} & $\lambda_{12}^{-}$ & $\beta_{12}^{-}$ & $\mu_{12}^{-}$ \\
\hline & & 0.118 & $-1.457 \cdot 10^{-9}$ & $2.136 \cdot 10^{-17}$ \\
\hline & & $\lambda_{21}^{-}$ & $\beta_{21}^{-}$ & $\mu_{21}^{-}$ \\
\hline & & 0.06 & $1.77 \cdot 10^{-9}$ & $2.947 \cdot 10^{-17}$ \\
\hline & & $\lambda_{13}^{-}$ & $\beta_{13}^{-}$ & $\mu_{13}^{-}$ \\
\hline & & 0.264 & $-1.118 \cdot 10^{-9}$ & $3.01 \cdot 10^{-17}$ \\
\hline & & $\lambda_{23}^{-}$ & $\beta_{23}^{-}$ & $\mu_{23}^{-}$ \\
\hline & & 0.189 & $2.156 \cdot 10^{-9}$ & $2.104 \cdot 10^{-17}$ \\
\hline & & $\lambda_{31}^{-}$ & $\beta_{31}^{-}$ & $\mu_{31}^{-}$ \\
\hline & & 0.134 & $-0.457 \cdot 10^{-10}$ & $5.819 \cdot 10^{-17}$ \\
\hline
\end{tabular}




\begin{tabular}{|c|c|c|c|c|}
\hline 1 & 2 & 3 & 4 & 5 \\
\hline \multirow{6}{*}{ 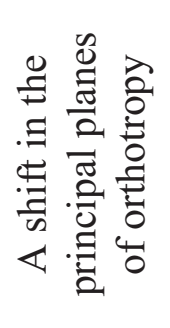 } & \multirow{6}{*}{$G_{k m}\left(\sigma_{i}\right), \mathrm{Pa}$} & $g_{12}$ & $p_{12}$ & $q_{12}$ \\
\hline & & $4.07 \cdot 10^{9}$ & $-1,6$ & $-8.38 \cdot 10^{-6}$ \\
\hline & & $g_{23}$ & $p_{23}$ & $q_{23}$ \\
\hline & & $1.723 \cdot 10^{9}$ & 16.899 & $-1.1 \cdot 10^{-5}$ \\
\hline & & $g_{31}$ & $p_{31}$ & $q_{31}$ \\
\hline & & $2.43 \cdot 10^{9}$ & -54.455 & $-1.97 \cdot 10^{-5}$ \\
\hline
\end{tabular}

Deformations $e_{z}$ are not explicitly included here, but they are easily computed from the third equation of the system (4).

Taking as a basis the new physical equations, we thus do not make changes in the dependence of the static-geometric nature, and therefore the static conditions for the annular plates in a cylindrical coordinate system will be presented in the traditional form $[29,30]$

$$
\begin{gathered}
N_{r, r}+\left(N_{r}-N_{\theta}\right) / r=0 ; \\
Q_{r, r}+Q_{r} / r=-q ; \\
M_{r, r}+\left(M_{r}-M_{\theta}\right) / r-Q_{r}=0 ;
\end{gathered}
$$

where $N_{r}, N_{\theta}, \mathrm{Q}_{\mathrm{r}}, M_{r}, M_{\theta}$ - forces and moments in cross sections of plate.

Forces and moments are determined by integrating expressions for stresses (6) over the plate thickness:

$$
\begin{gathered}
N_{r}=\int_{-h / 2}^{h / 2} \sigma_{r} d z ; \quad N_{\theta}=\int_{-h / 2}^{h / 2} \sigma_{\theta} d z ; \\
Q_{r}=\int_{-h / 2}^{h / 2} \tau_{r z} d z ; \\
M_{r}=\int_{-h / 2}^{h / 2} \sigma_{r} \cdot z d z ; \quad M_{\theta}=\int_{-h / 2}^{h / 2} \sigma_{\theta} \cdot z d z ;
\end{gathered}
$$

From the joint consideration of dependences (6) - (9), the resolving equations of axisymmetric bending of plates of average thickness having cylindrical orthotropy and nonlinear dependence of mechanical characteristics of the material on the type of stress state follow:

$$
\begin{aligned}
& D_{11, r} \cdot u_{, r r}+K_{11, r} \cdot \psi_{\theta, r r}+D_{12, r} \cdot u_{, r} / r+ \\
& +K_{12, r} \cdot \psi_{\theta, r} / r+\left(D_{11} \cdot u_{, r}+K_{11} \cdot \psi_{\theta, r}+\right. \\
& +D_{12} \cdot u / r+K_{12} \cdot \psi_{\theta} / r-D_{12} \cdot u_{, r}+ \\
& \left.+K_{12} \psi_{\theta, r}+D_{22} \cdot u / r+K_{22} \cdot \psi_{\theta} / r\right) / r=0 \text {; } \\
& D_{13, r} \cdot\left(w_{, r r}+\psi_{\theta, r}\right)+D_{13}\left(w_{, r}+\psi_{\theta}\right) / r=-q ;(10) \\
& \left(\begin{array}{c}
K_{11} \cdot u_{, r}+R_{11} \cdot \psi_{\theta, r}+K_{12} \cdot u / r+ \\
+R_{12} \cdot \psi_{\theta} / r-K_{12} u_{, r}+R_{12} \cdot \psi_{\theta, r}+ \\
6 K_{22} u / r+R_{22} \cdot \psi_{\theta} / r
\end{array}\right) / r- \\
& -D_{13} \cdot\left(w_{, r}+\psi_{\theta}\right)=0 \text {. }
\end{aligned}
$$

where $D_{11}, D_{12}, D_{22}, D_{13}, K_{11}, K_{12}, K_{22}, R_{11}, R_{12}$, $R_{22}$ - the integral of the function on the plate thickness, resulting after integration by formulas (9); $D_{11, r}, D_{12, r}, D_{33, r}, K_{11, r}, K_{12, r}, R_{11, r}, R_{12, r}-$ derivatives of integral functions on the radial coordinate.

To solve the obtained equations (10) we use the finite-difference method with the second-order approximation of accuracy $[32,33]$.

\section{RESULTS AND DISCUSSION}

To solve this class of problems the program is developed in MatLAB. Considered 2 options for fixing the plate: hinge and rigid clamping at the edges. Also, 3 variants of the decision were considered. For clarity, each of the solutions is indicated by its own, different from the other line:

- considered model [27, 28, 29];

- - - solutions without taking into account the properties of resistivity taking into account the stiffness of the material only in axial tension; 
Bending of Ring Plates, Performed from an Orthotropic Nonlinear Differently Resistant Material

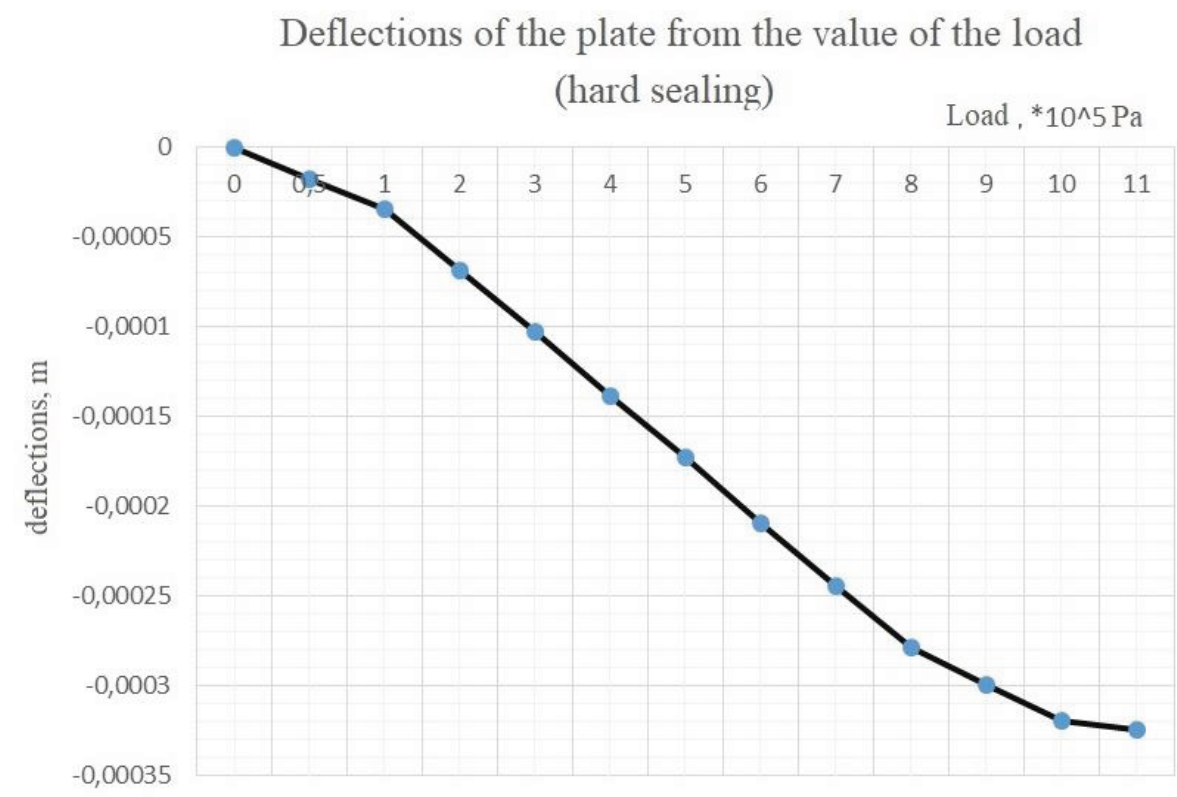

Figure 2. Deflections of the plate from the load.

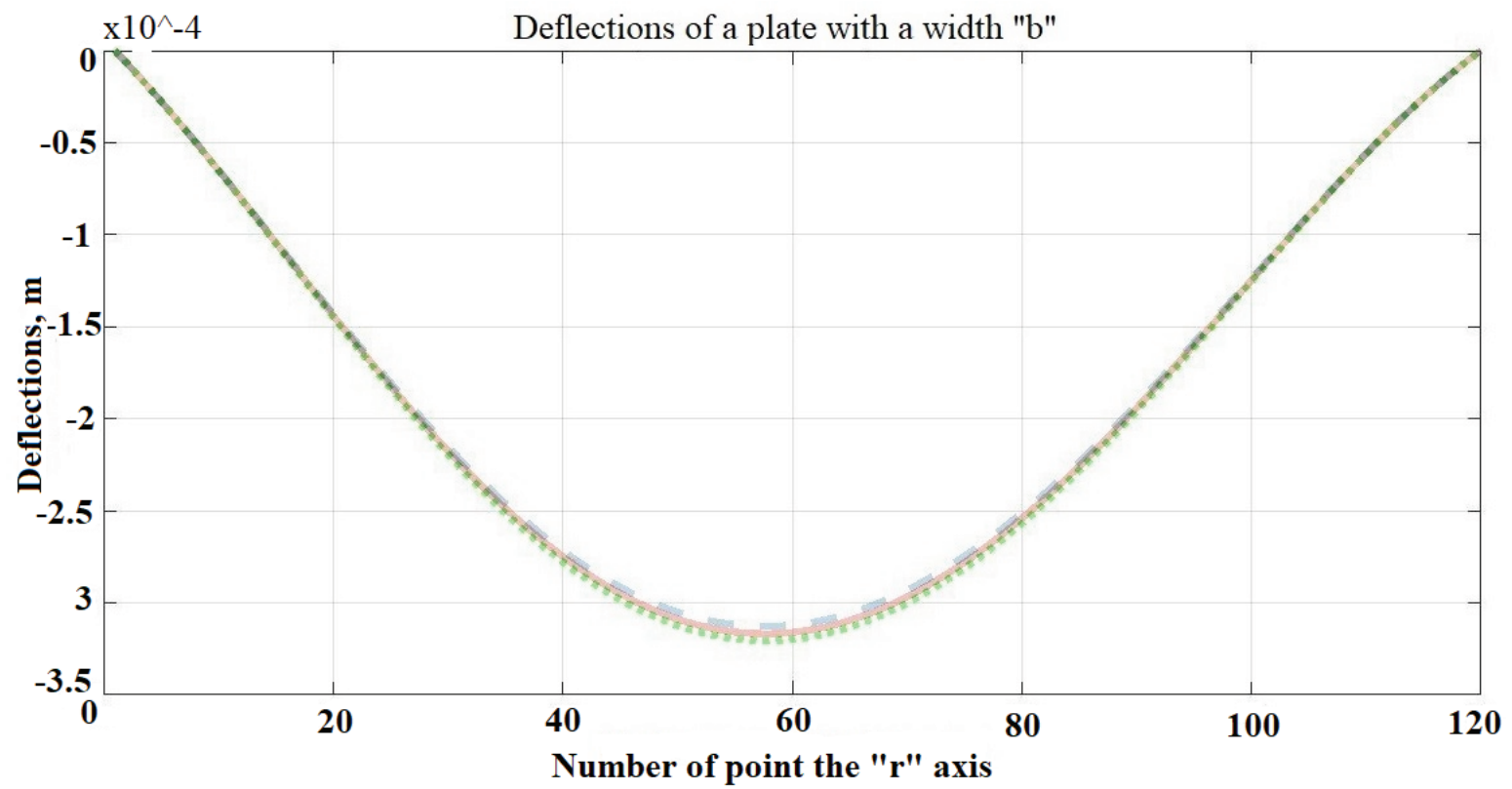

Figure 3. Deflection of the plate along the coordinate $r$.

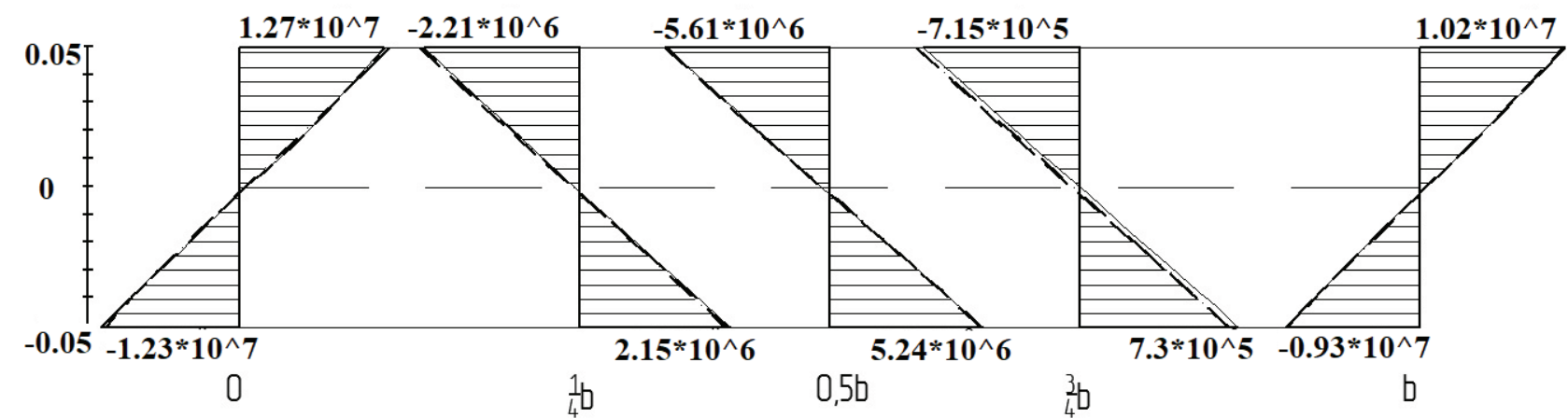

Figure 4. Stress distribution $\sigma_{r}$ over the thickness of the annular plate in typical cross-sections, $P A$.

Volume 16, Issue 1, 2020 


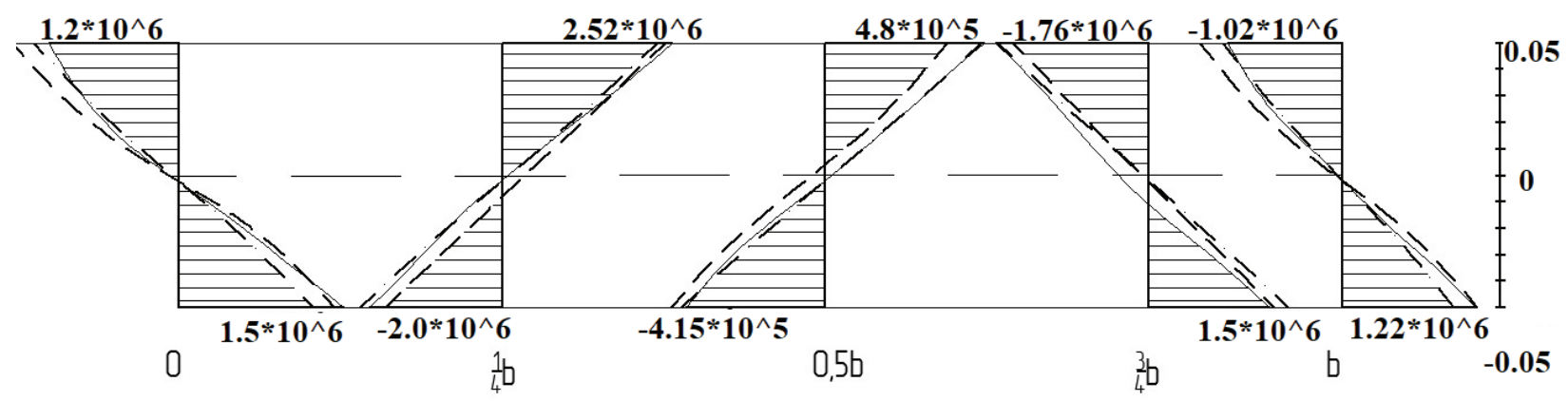

Figure 5. Stress distribution $\sigma_{\theta}$ over the thickness of the annular plate in typical cross-sections, PA.

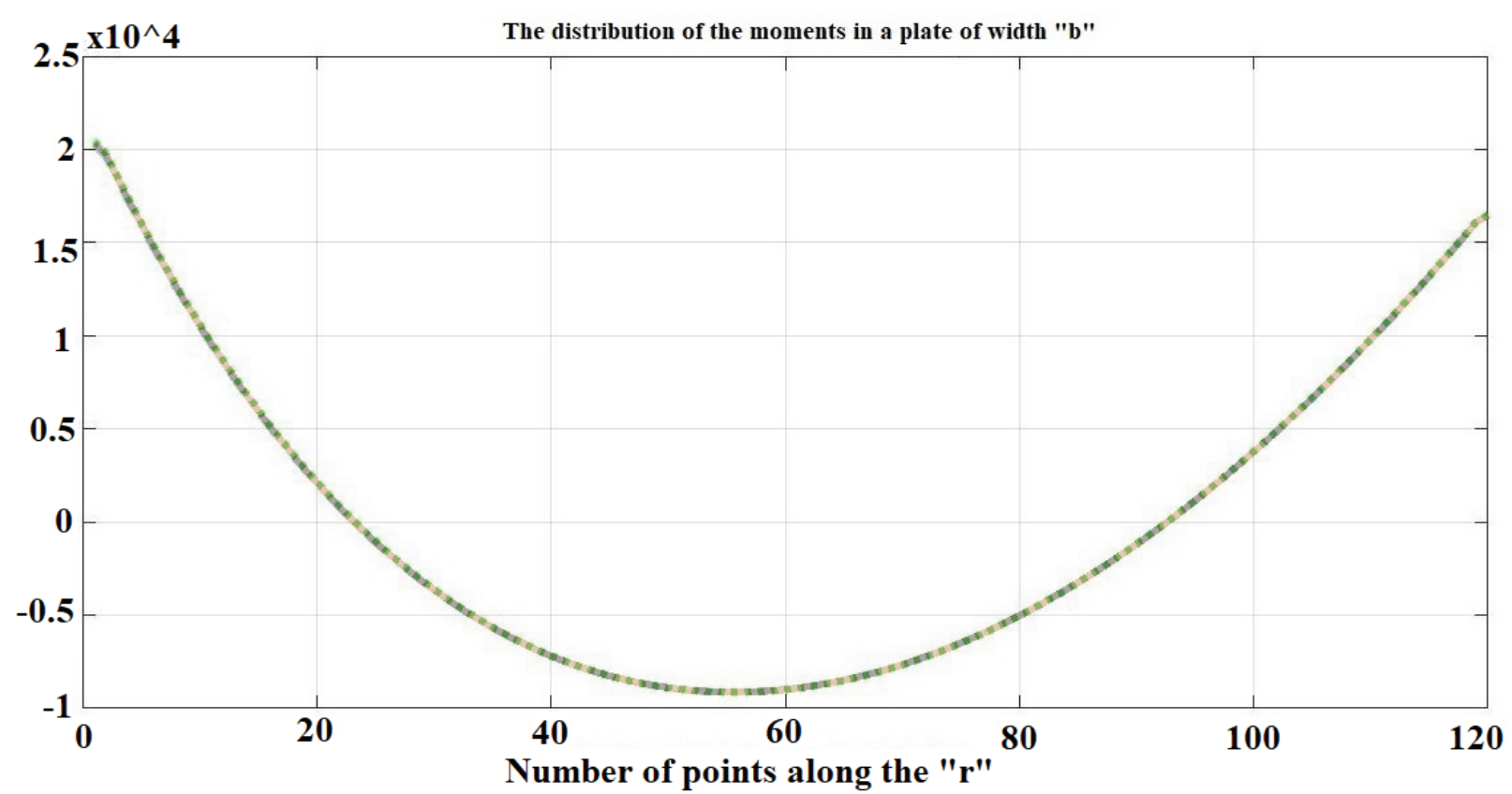

Figure 6. Distribution of $M_{r}$ moments on the annular plate.

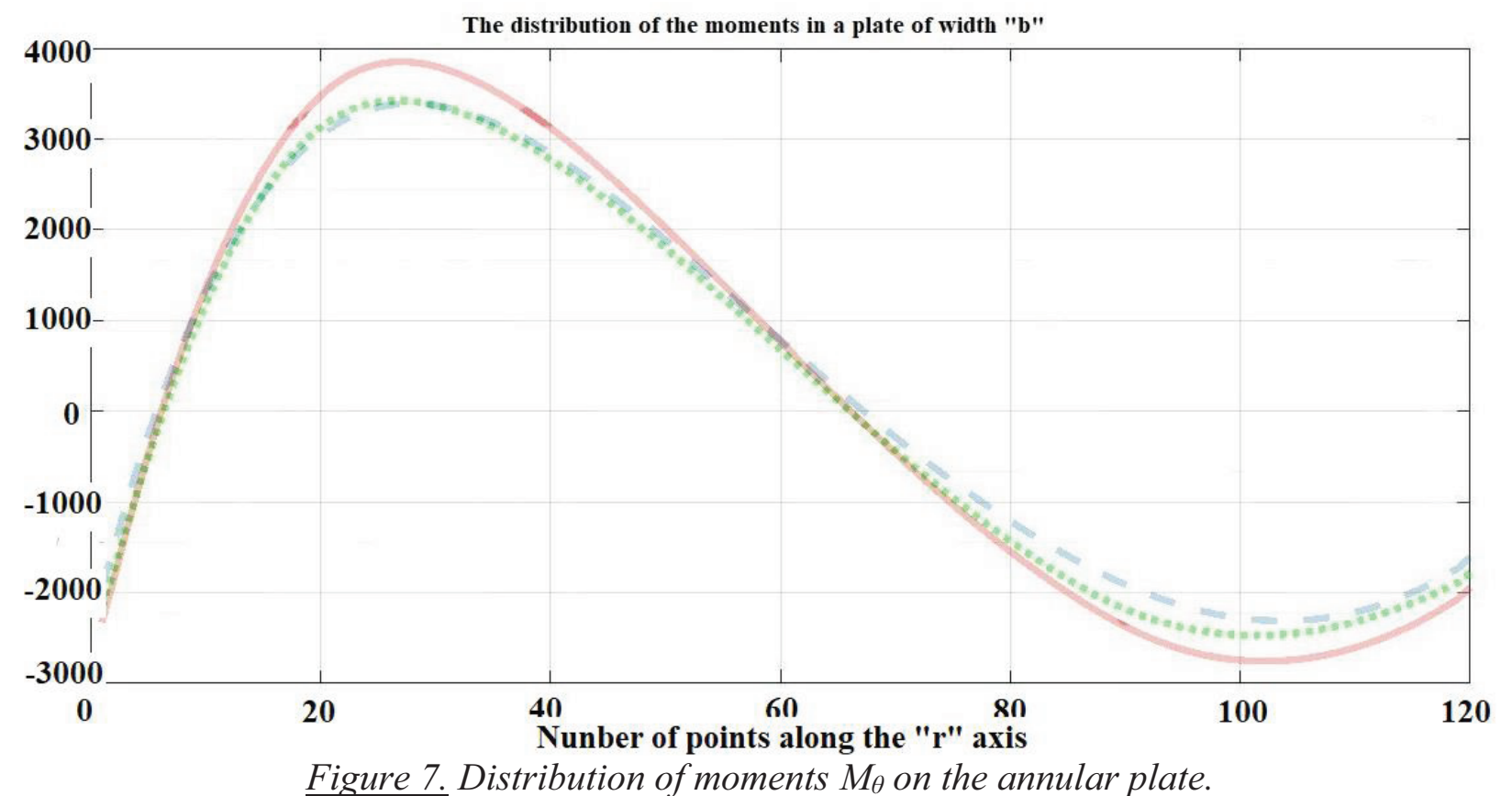


Bending of Ring Plates, Performed from an Orthotropic Nonlinear Differently Resistant Material

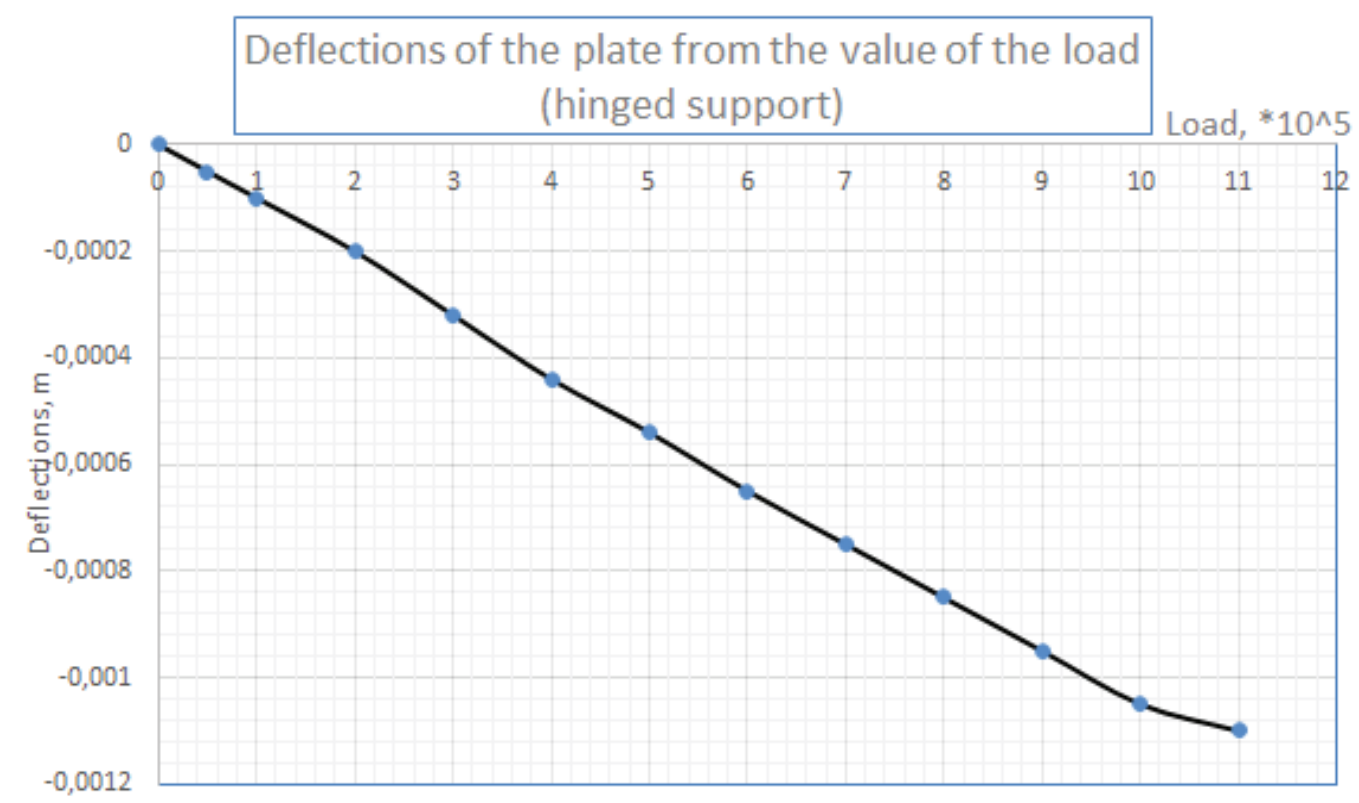

Figure 8. Deflections of the plate from the load.

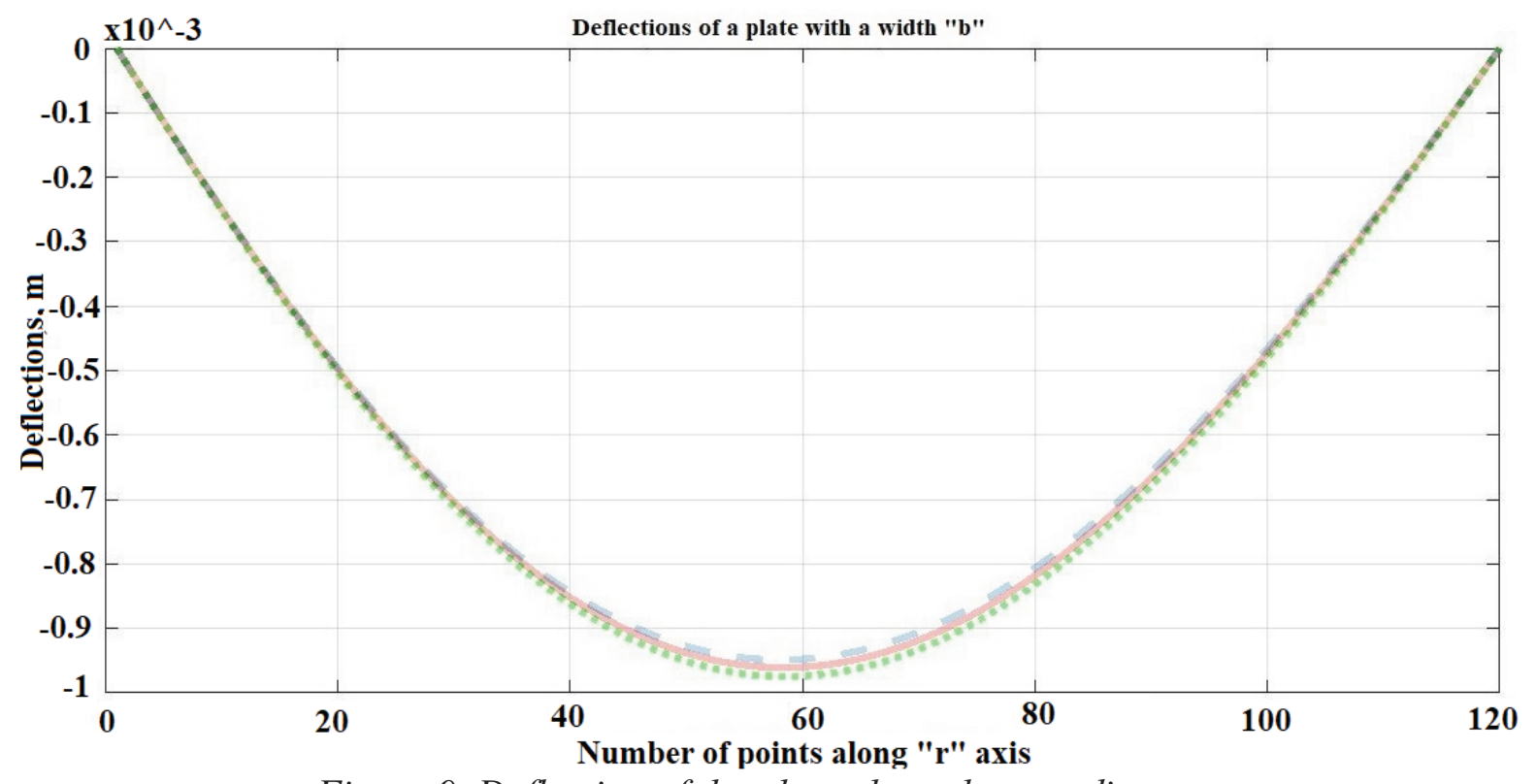

Figure 9. Deflection of the plate along the coordinate $r$.

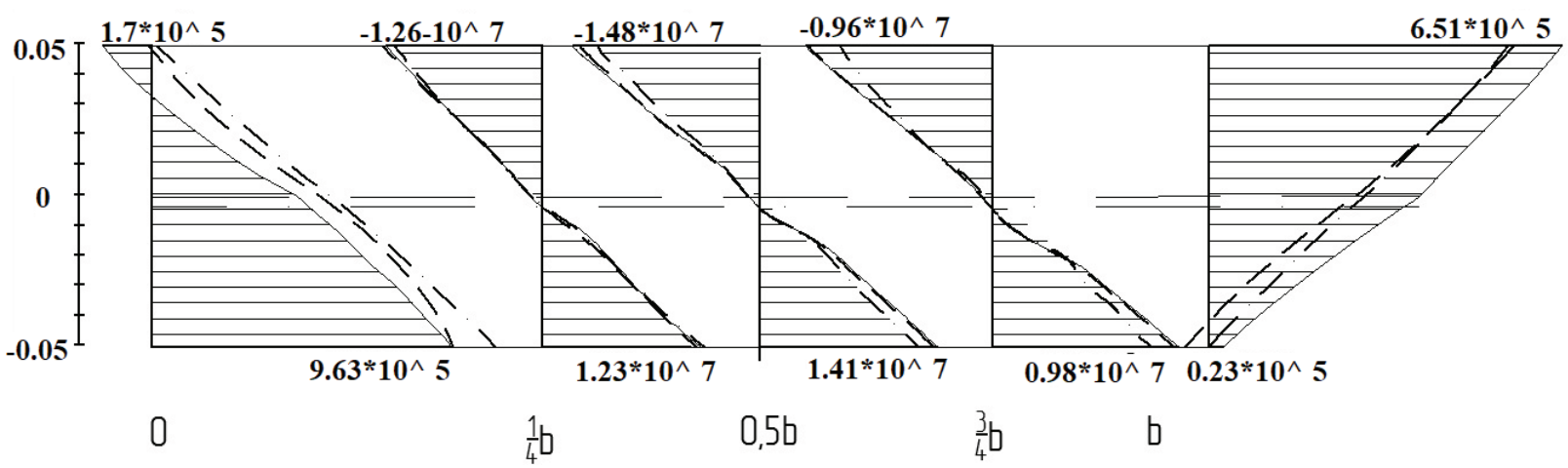

Figure 10. Stress distribution $\sigma_{r}$ over the thickness of the annular plate in typical cross-sections, PA 


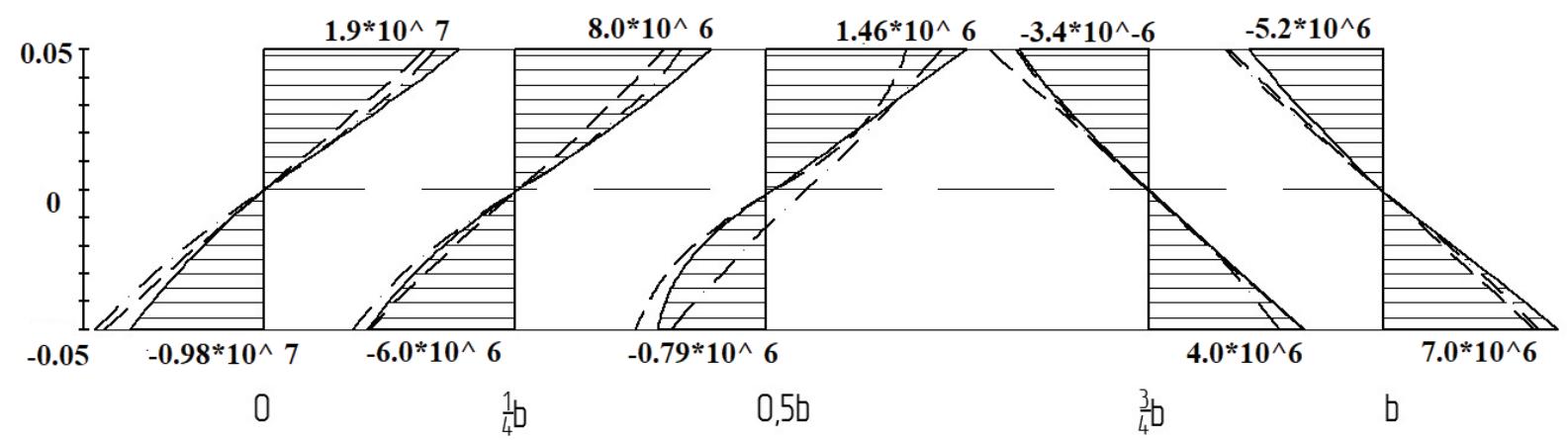

Figure 11. Stress distribution $\sigma_{\theta}$ over the thickness of the annular plate in typical cross-sections, $P A$

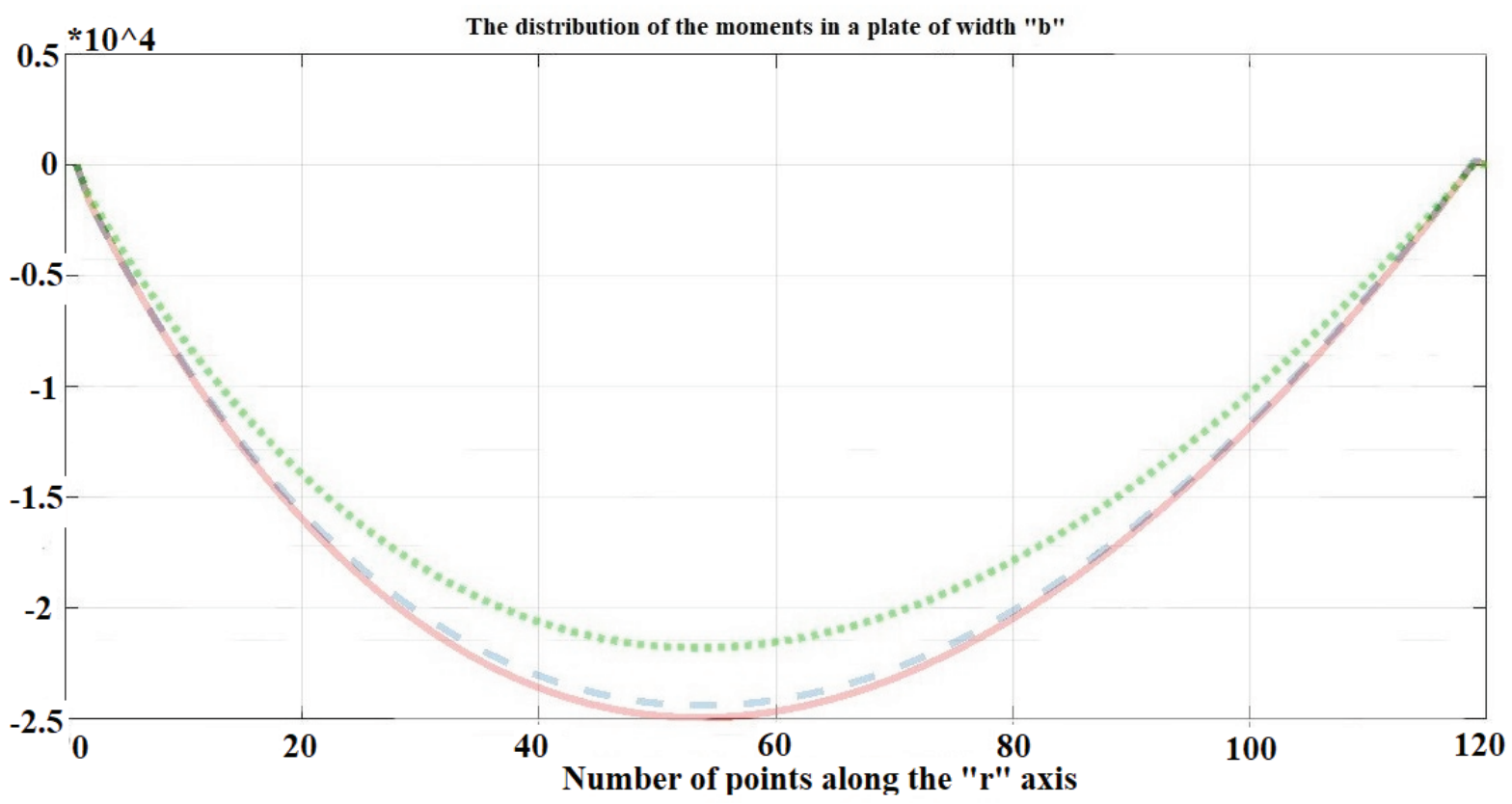

Figure 12. Distribution of $M_{r}$ moments on the annular plate.

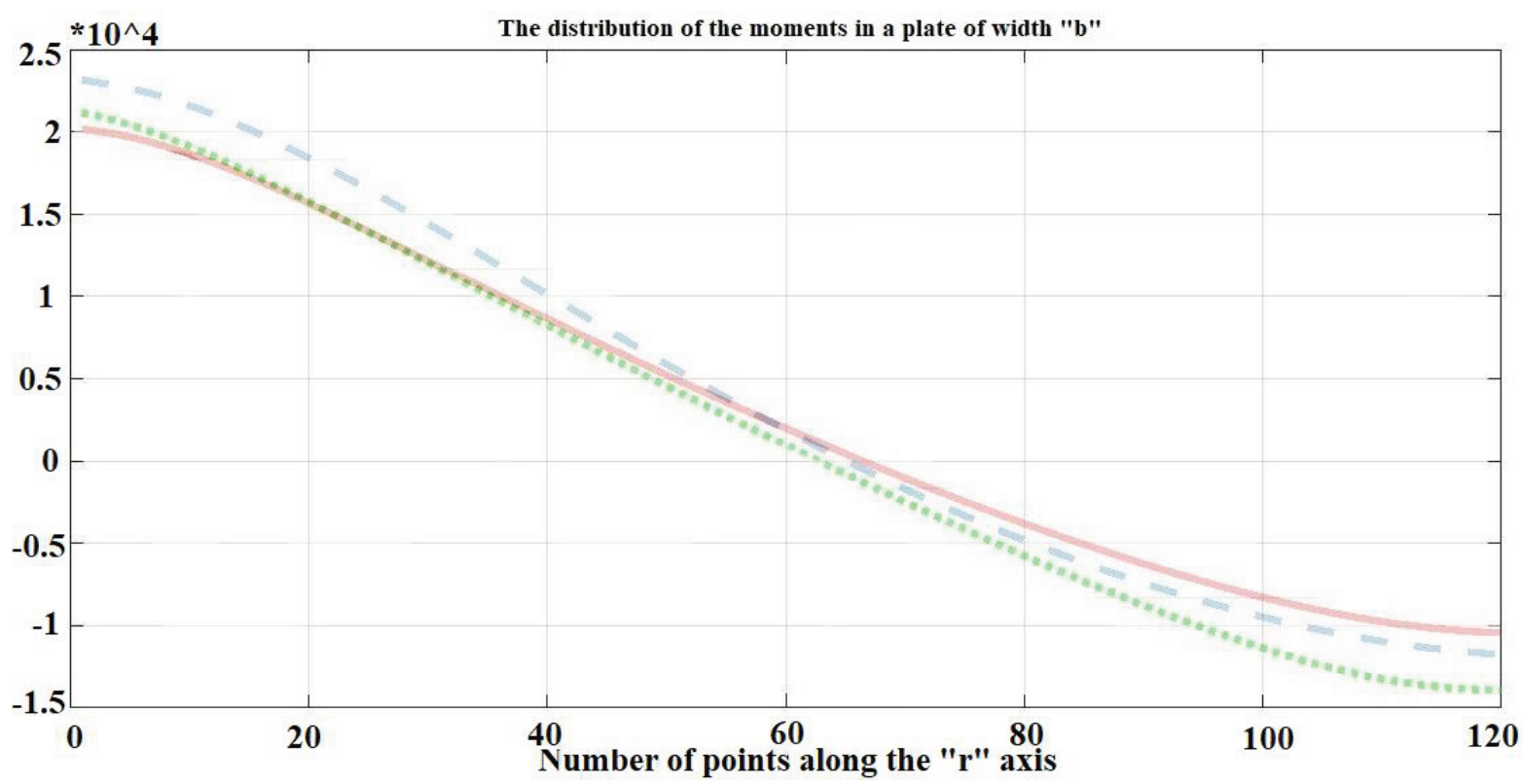

Figure 13. Distribution of moments $M_{\theta}$ on the annular plate. 
......- solutions without taking into account the properties of resistivity, taking into account the stiffness of the material only in axial compression.

After processing the calculation results, the following graphs and charts were obtained:

- deflections from the load value;

- deflections on the coordinate "r";

- distribution of stresses in the plate in different sections;

- horizontal movement and rotation angles of the middle surface of the plate;

- distribution of moments in the plate.

The main results are given on the graphs for the section of the ring plate "R-a". From 2 to 11 figure shows the results of the calculation of the plate with a rigid clamping, and from 14 to 21 figure - with a hinge support.

\section{SUMMARY}

During the implementation of the model of deformation of ring plates under the action of uniformly distributed loads, the basic values of the parameters characterizing their stress-strain states are obtained.

As a result of comparison of the solutions of the considered problems on the presented deformation model with the data of the traditional nonlinear theory without taking into account the properties of the resistivity, the following features characterizing the differences in the stress-strain state parameters are noted:

1) A rigidly fixed plate:

- the difference in deflections is $1.3 \%$;

- the difference in the values of forces in different sections of the annular plate varies in the range of $1.5-3 \%$ for $\sigma \mathrm{r} ; 13-17 \%$ for $\sigma \mathrm{rz} ; 5-7 \%$ for $\sigma \theta$;

- c. the difference in horizontal displacement values is $6 \%$;

- $d$. the difference in the values of the angles of rotation is $4 \%$;

- e. the difference in the values of the moment of $\mathrm{Mr}$ is $0.5-1 \%$; and $\mathrm{M} \theta-10-15 \%$.

2) Hinged plate:
- a. the difference in deflections is $1.5-2 \%$;

- b. the difference in the stress values in different sections of the annular plate varies in the range of $7-15 \%$ for or; $5-19 \%$ for orz; $10-14 \%$ for $\sigma \theta$;

- c. the difference in the values of horizontal displacements is $2-4 \%$;

- $d$. the difference in the values of the angles of rotation is $15-17 \%$;

- e. the difference in the moment $\mathrm{Mr}$ is $15 \%$; and $\mathrm{M} \theta-25 \%$.

Thus, it is established that the non-linear material resistivity is not taken into account when considering the deformation parameters of various structures made of such materials, which leads to noticeable errors.

\section{CONCLUSIONS}

As a result of the study, a model of deformation of orthotropic materials was concretized and applied, which most accurately and adequately describes most of the currently known nonlinear materials. The model is based on the processed results of experiments on deformation of materials with different resistance, material nonlinear functions and constants [30].

To solve the problem of deformation of a ring plate from a nonlinear orthotropic material according to the developed model, the method of variable parameters of elasticity with a finitedifference approximation of the second order of accuracy was used. Developed the algorithm of decision of task "calculation of axisymmetric deformation of circular plates, the average thickness of the non-linear orthotropic resistive materials with small deflections". Practical application of the algorithm and evaluation of iterative methods of the solution were implemented with the help of "MatLAB" software package.

As a result of the work done, a number of test problems on the topic of deformation of plates of average thickness from nonlinear orthotropic materials were solved, the parameters of the state of the plates at different stages of loading 
by a transverse uniformly distributed load were determined, two options for fixing the ring plates were considered, the results of comparing three.

\section{REFERENCES}

1. Ambartsumyan S.A. Teorija anizotropnyh plastin: prochnost', ustojchivost', kolebanija [Theory of anisotropic plates: strength, stability, vibrations]. Moscow, Nauka, 1967, 266 pages (in Russian).

2. Ambartsumyan S.A. Osnovnye uravnenija i sootnoshenija raznomodul'noj teorii uprugosti anizotropnogo tela [Basic equations and ratios of the multi-modular theory of elasticity of an anisotropic body]. // Izv. Academy of Sciences of the USSR. MTT, 1969, Vol. 3, pp. 51-61 (in Russian).

3. Ambartsumyan S.A. Raznomodul'naja teorija uprugosti [Multi-modular theory of elasticity]. Moscow, Nauka, 1982, 320 pages (in Russian).

4. Ambartsumyan S.A., Khachatryan A.A. Osnovnye uravnenija teorii uprugosti dlja materialov, raznosoprotivljajushhihsja rastjazheniju i szhatiju [The basic equations of the theory of elasticity for materials of different resistance to tension and compression]. // Inzh. journals MTT, 1966, Vol. 2, pp. 44-53 (in Russian).

5. Ambartsumyan S.A., Khachatryan A.A. $\mathrm{K}$ raznomodul'noj teorii uprugosti [Towards a multimodular theory of elasticity]. // Ing. journals MTT, 1966, Vol. 6, pp. 64-67 (in Russian).

6. Jones R.M. A Nonsystemmetric Compliance Matrix Approach to Nonlinear Multimoduls Ortotropic Materials. // AIAA Journal, 1977, Vol. 15, Issue 10, pp. 14361443.

7. Jones R.M., Nelson D.A.R. Material for nonlinear Deformation. // AIAA Journal, 1976, Vol. 14, Issue 6, pp. 709-716.

8. Jones R.M. Modeling Nonlinear Deformation of the Carbon-Carbon Composite
Materials. // AIAA Journal, 1980, Vol. 18, Issue 8, pp. 995-1001.

9. Jones R.M. Stress-Strain Relations for Materials with Moduli in Tension and Compression. // AIAA Journal, 1977, Vol. 15, Issue 1, pp. 16-25.

10. Bert C.W. Models for Fibrous Composites. // Transaction of the ASME, 1977, Vol. 99 H. - Ser. D., Issue 4, pp. 344-349.

11. Bert C.W. Micromechanics of the different elastic behavior of filamentary composite in tension and compression. Mechanics of bimodulus materials. New York, ASME, 1979, pp. 17-28.

12. Bert C.W., Gordaninejad F. Multimodular Materials. // International Journal for Numerical Methods in Engineering, 1984, Vol. 20, pp. 479-503.

13. Bert C.W., Reddy J.N., Chao W.C. Bending of Thick Rectanqular Plates Laminated of Bimodulus Composite Materials. // AIAA Journal, 1981, Vol. 19, Issue 10, pp. 13421349.

14. Zolochevsky A.A. K tenzornoj svjazi v teorijah uprugosti i plastichnosti anizotropnyh kompozitnyh materialov, raznosoprotivljajushhihsja rastjazheniju i szhatiju [To tensor coupling in the theories of elasticity and plasticity of anisotropic composite materials that are differently opposed to tension and compression]. // $\mathrm{Me}$ chanics of composite materials, 1985, Vol. 1, pp. 53-58 (in Russian).

15. Zolochevsky A.A. Opredeljajushhie uravnenija i nekotorye zadachi raznomodul'noj teorii uprugosti anizotropnyh materialov [Determining equations and some problems of the multimodular theory of elasticity of anisotropic materials]. // PMTF, 1985, Issue 4, pp. 131138 (in Russian).

16. Zolochevsky A.A. $\mathrm{K}$ teorii plastichnosti materialov razlichno soprotivljajushhihsja rastjazheniju i szhatiju [On the theory of plasticity of materials differently resisting tension and compression]. // Izv. universi- 
ties. Engineering, 1986, Vol. 6, pp. 13-16 (in Russian).

17. Zolochevsky A.A. O sootnoshenijah teorii uprugosti anizotropnyh raznomodul'nyh materialov [On the relations of the theory of elasticity of anisotropic multi-modular materials]. // Dynamics and durability of machines. Kharkov, High school, 1981, Vol. 34, pp. 3-8 (in Russian).

18. Zolochevsky A.A. Sootnoshenija raznomodul'noj teorii uprugosti anizotropnyh materialov na osnove treh smeshannyh invariantov. // Dynamics and Strength of Machines. Kharkov, High school, 1987, Vol. 46, pp. 85-89 (in Russian).

19. Zolochevsky A.A., Morachkovsky O.K. Napravlenija razvitija modelej i metodov rascheta nelinejnogo deformirovanija tel i jelementov mashinostroitel'nyh konstrukcij [The directions of development of models and methods for calculating the nonlinear deformation of bodies and elements of engineering structures]. // Dynamics and strength of machines. Kharkov, High school, 1989, Vol. 50, pp. 3-9 (in Russian).

20. Zolochevsky A.A., Sklepus S.N. K teorii plastichnosti s tremja invariantami naprjazhennogo sostojanija [On the theory of plasticity with three invariants of the stress state]. // Izv. universities. Engineering, 1987, Vol. 5, pp. 7-10 (in Russian).

21. Zolochevsky A.A. Ob uchete raznosoprotivljaemosti v teorii polzuchesti izotropnyh $i$ anizotropnyh materialov [Concerning consideration of the multiresistance in the theory of creep of isotropic and anisotropic materials]. // PMTF, 1982, Vol. 4, pp. 140-144 (in Russian).

22. Lomakin E.V. Raznomodul'nost' kompozitnyh materialov [Multi-modularity of composite materials]. // Mechanics of composite materials, 1981, Vol. 1, pp. 2329 (in Russian).

23. Lomakin E.V. Sootnoshenija teorii uprugosti dlja anizotropnogo tela, deformacionnye harakteristiki kotoryh zavisjat ot vida naprjazhennogo sostojanija [Relations of the theory of elasticity for an anisotropic body, the deformation characteristics of which depend on the type of stress state]. // Izv. Academy of Sciences of the USSR. MTT, 1983, Issue 3, pp. 63-69.

24. Berezin I.S., Zhidkov N.P. Metody vychislenij [Calculation methods]. Volumes 1, 2. Moscow, State. publishing house physical. lit-ry, 1959, 464 pages (in Russian).

25. Matchenko N.M., Treshchev A.A. Uchet vlijanija vida naprjazhennogo sostojanija na uprugie i plasticheskie sostojanija nachal'no izotropnyh deformiruemyh sred [Accounting for the influence of the type of stress state on elastic and plastic states of initially isotropic deformable media]. // Abstracts of the reports of the International Scientific and Technical Symposium, "Modeling and similarity criteria in the processes of developed plastic form change”. Orel, OPT, 1996, pp. 11-12 (in Russian).

26. Matchenko N.M., Treshchev A.A. Teorija deformirovanija raznosoprotivljajushhihsja materialov. Tonkie plastiny i obolochki [Theory of deformation of materials with different resistance. Thin plates and shells]. Moscow, Tula: RAACS, TSU, 2005, 187 pages (in Russian).

27. Treschev A.A. Opisanie nelinejnogo deformirovanija anizotropnyh materialov [Description of non-linear deformation of anisotropic materials]. // Actual problems of the construction and construction industry: a collection of materials of the International Conference. Tula, TSU, 2001, pp. 107108 (in Russian).

28. Treschev A.A. Opisanie deformirovanija nelinejnyh anizotropnyh materialov [Description of the deformation of nonlinear anisotropic materials]. // Architectural and building materials science at the turn of the century: materials of reports of the International Conference. Belgorod, BelGTASM, 2002, pp. 86 (in Russian).

29. Treschev A.A. Teorija deformirovanija i prochnosti materialov $\mathrm{s}$ iznachal'noj 
navedjonnogo chuvstvitel'nost'ju $\mathrm{k}$ vidu naprjazhjonno-go sostojanija. Opredeljajushhie sootnoshenija [The theory of deformation and strength of materials with initial induced sensitivity to the type of stress state. Defining relationships]. Moscow, Tula, RAACS, TulSU, 2016, 328 pages (in Russian).

30. Treschev A.A. Anizotropnye plastiny i obolochki iz raznosoprotivljajushhihsja materialov [Anisotropic plates and shells from materials of different resistance]. Moscow, Tula, RAACS, TSU, 2007, 160 pages (in Russian).

31. Jones R.M., Nelson D.A.R. Theoreticalexperimental correlation of material models for non-linear deformation of graphite. // AIAA Journal, 1976, Vol. 14, No. 10, pp. 1427-1435.

32. Birger I.A., Mavlyutov R.R. Soprotivlenie materialov [Resistance materials]. Moscow, Science. Ch. ed. Phys.-Mat. lit., 1986, 560 pages (in Russian).

33. Pisarenko G. S., Mozharovsky N. S. Uravnenija i kraevye zadachi teorii plastichnosti $i$ polzuchesti [Equations and boundary value problems of the theory of plasticity and creep]. Kiev, Science Dumka, 1981, 496 pages (in Russian).

\section{СПИСОК ЛИТЕРАТУРЫ}

1. Амбарцумян С.А. Теория анизотропных пластин: прочность, устойчивость, колебания. - М.: Наука, 1967. - 266 с.

2. Амбарцумян С.А. Основные уравнения и соотношения разномодульной теории упругости анизотропного тела. // Изв. АН СССР. МТТ, 1969, №3, с. 51-61.

3. Амбарцумян С.А. Разномодульная теория упругости. - М.: Наука, 1982. $320 \mathrm{c}$.

4. Амбарцумян С.А., Хачатрян А.А. Основные уравнения теории упругости для материалов, разносопротивляющихся растяжению и сжатию. // Инж. журн. МТT, 1966, №2, c. 44-53.

5. Амбарцумян С.А., Хачатрян А.А. К разномодульной теории упругости. // Инж. журрн. МТТ, 1966, №6, с. 64-67.

6. Jones R.M. A Nonsystemmetric Compliance Matrix Approach to Nonlinear Multimoduls Ortotropic Materials. // AIAA Journal, 1977, Vol. 15, Issue 10, pp. 14361443.

7. Jones R.M., Nelson D.A.R. Material for nonlinear Deformation. // AIAA Journal, 1976, Vol. 14, Issue 6, pp. 709-716.

8. Jones R.M. Modeling Nonlinear Deformation of the Carbon-Carbon Composite Materials. // AIAA Journal, 1980, Vol. 18, Issue 8, pp. 995-1001.

9. Jones R.M. Stress-Strain Relations for Materials with Moduli in Tension and Compression. // AIAA Journal, 1977, Vol. 15, Issue 1, pp. 16-25.

10. Bert C.W. Models for Fibrous Composites. // Transaction of the ASME, 1977, Vol. 99 H. - Ser. D., Issue 4, pp. 344-349.

11. Bert C.W. Micromechanics of the different elastic behavior of filamentary composite in tension and compression. Mechanics of bimodulus materials. New York, ASME, 1979, pp. 17-28.

12. Bert C.W., Gordaninejad F. Multimodular Materials. // International Journal for Numerical Methods in Engineering, 1984, Vol. 20, pp. 479-503.

13. Bert C.W., Reddy J.N., Chao W.C. Bending of Thick Rectanqular Plates Laminated of Bimodulus Composite Materials. // AIAA Journal, 1981, Vol. 19, Issue 10, pp. 13421349.

14. Золочевский А.А. К тензорной связи в теориях упругости и пластичности анизотропных композитных материалов, разносопротивляющихся растяжению и сжатию. // Механика композитных материалов, 1985, №1, с. 53-58.
15. Золочевский
А.А. Определяющие уравнения и некоторые задачи разномодульной теории упругости 
анизотропных материалов. // ПМТФ, 1985, №4, с. 131-138.

16. Золочевский А.А. К теории пластичности материалов различно сопротивляющихся растяжению и сжатию. // Известия вузов. Машиностроение, 1986, №6, с. 13-16.

17. Золочевский А.А. $\mathrm{O}$ соотношениях теории упругости анизотропных разномодульных материалов. // Динамика и прочность машин. Харьков: Вища школа, 1981, Выпуск 34, c. 3-8.

18. Золочевский А.A. Соотношения разномодульной теории упругости анизотропных материалов на основе трех смешанных инвариантов. // Динамика и прочность машин. Харьков: Вища школа, 1987, Выпуск 46, c. $85-89$.

19. Золочевский А.А., Морачковский А.А. Направления развития моделей и методов расчета нелинейного деформирования тел и элементов машиностроительных конструкций. // Динамика и прочность машин. Харьков: Вища школа, 1989, Выпуск 50, c. 3-9.

20. Золочевский А.А., Склепус С.Н. К теории пластичности с тремя инвариантами напряженного состояния. // Известия вузов. Машиностроение, 1987 , №5, c. 7-10.

21. Золочевский А.А. Об учете разносопротивляемости в теории ползучести изотропных и анизотропных материалов. // ПМТФ, 1982, №4, с. 140144.

22. Ломакин Е.В. Разномодульность композитных материалов. // Механика композитных материалов, 1981, №1, с. 23-29.

23. Ломакин Е.В. Соотношения теории упругости для анизотропного тела, деформационные характеристики которых зависят от вида напряженного состояния. // Известия АН СССР. МТТ, 1983, №3, c. 63-69.

24. Березин И.С., Жидков Н.П. Методы вычислений. В двух томах. Том 1. - М.: Государственное издательство физикоматематической литературы, 1959. $464 \mathrm{c}$.

25. Матченко Н.М., Трещев А.А. Учет влияния вида напряженного состояния на упругие и пластические состояния начально изотропных деформируемых сред. // Tезисы докладов Международного научно-технического симпозиума, «Моделирование и критерии подобия в прочессах развитого пластического формоизменения». - Орел: ОПТУ, 1996, c. 11-12.

26. Матченко Н.М., Трещев А.А. Теория деформирования разносопротивляющихся материалов. Тонкие пластины и оболочки. - М.; Тула: РААСН; ТулГУ, 2005. $-187 \mathrm{c}$.

27. Трещев А.А. Описание нелинейного деформирования анизотропных материалов. // Актуальные проблемы строительства и строительной индустрии: сборник материалов Международной конференции. - Тула: ТулГУ, 2001, с. 107-108.

28. Трещев А.А. Описание деформирования нелинейных анизотропных материалов. // Архитектурно-строчтельное материаловедение на рубеже веков: материаль докладов Международной конферениии. - Белгород: БелГТАСМ, 2002, c. 86.

29. Трещев А.А. Теория деформирования и прочности материалов с изначальной наведённого чувствительностью к виду напряжённого состояния. Определяющие соотношения. - М.: - Тула: РАACH, ТулГУ, 2016. - 328 с.

30. Трещев А.А. Анизотропные пластины и оболочки из разносопротивляющихся материалов. - М.: - Тула: РАACH, ТулГУ, 2007. - 160 с. 
31. Jones R.M., Nelson D.A.R. Theoreticalexperimental correlation of material models for non-linear deformation of graphite. // AIAA Journal, 1976, Vol. 14, Issue 10, pp. 1427-1435.

32. Биргер И.А., Мавлютов P.P. Сопротивление материалов. - М.: Наука. Главная редакция физикоматематической литературы, 1986 $560 \mathrm{c}$.

33. Писаренко Г.С., Можаровский Н.С. Уравнения и краевые задачи теории пластичности и ползучести. - Киев: Наук. думка, 1981 - 496 с.

Трещев Александр Анатольевич, член-корреспондент Российской академии архитектуры и строительных наук (РААСН), профессор, доктор технических наук; заведующий кафедрой «Строительство, строительные материалы и конструкции», Тульский государственный университет; 300012, Россия, г. Тула, пр. Ленина, 92; тел. +7 (905) 622-90-58;

E-mail: taa58@yandex.ru.

Журин Евгений Андреевич, аспирант кафедры «Строительство, строительные материалы и конструкции», Тульский государственный университет; 300012, Россия, г. Тула, пр. Ленина, 92; тел. +7 (920) 276-01-46; e-mail: eazhurin@mail.ru.

Alexander A. Treschev, Corresponding Member of the Russian Academy of Architecture and Construction Sciences (RAACS), Professor, Doctor of Technical Sciences, Head of Department of Construction, Building Materials and Structures, Tula State University; 300012, Russia, Tula, Lenin Ave. 92; phone: +7 (905) 622-90-58;

E-mail: taa58@yandex.ru.

Evgeniy A. Zhurin, Graduate student of the department "Construction, building materials and structures", Tula State University; 300012, Russia, Tula, Lenin Ave. 92; phone: +7 (920) 276-01-46; e-mail: eazhurin@mail.ru. 